This item was submitted to Loughborough's Research Repository by the author.

Items in Figshare are protected by copyright, with all rights reserved, unless otherwise indicated.

\title{
Melt compounding of rigid PVC formulations with hydrotalcites
}

PLEASE CITE THE PUBLISHED VERSION

PUBLISHER

(C) Maney

VERSION

VoR (Version of Record)

LICENCE

CC BY-NC-ND 4.0

\section{REPOSITORY RECORD}

Hitt, David J., Barry Haworth, Noreen L. Thomas, and M.A. Algahtani. 2009. "Melt Compounding of Rigid PVC Formulations with Hydrotalcites”. figshare. https://hdl.handle.net/2134/4230. 
This item was submitted to Loughborough's Institutional Repository (https://dspace.lboro.ac.uk/) by the author and is made available under the following Creative Commons Licence conditions.

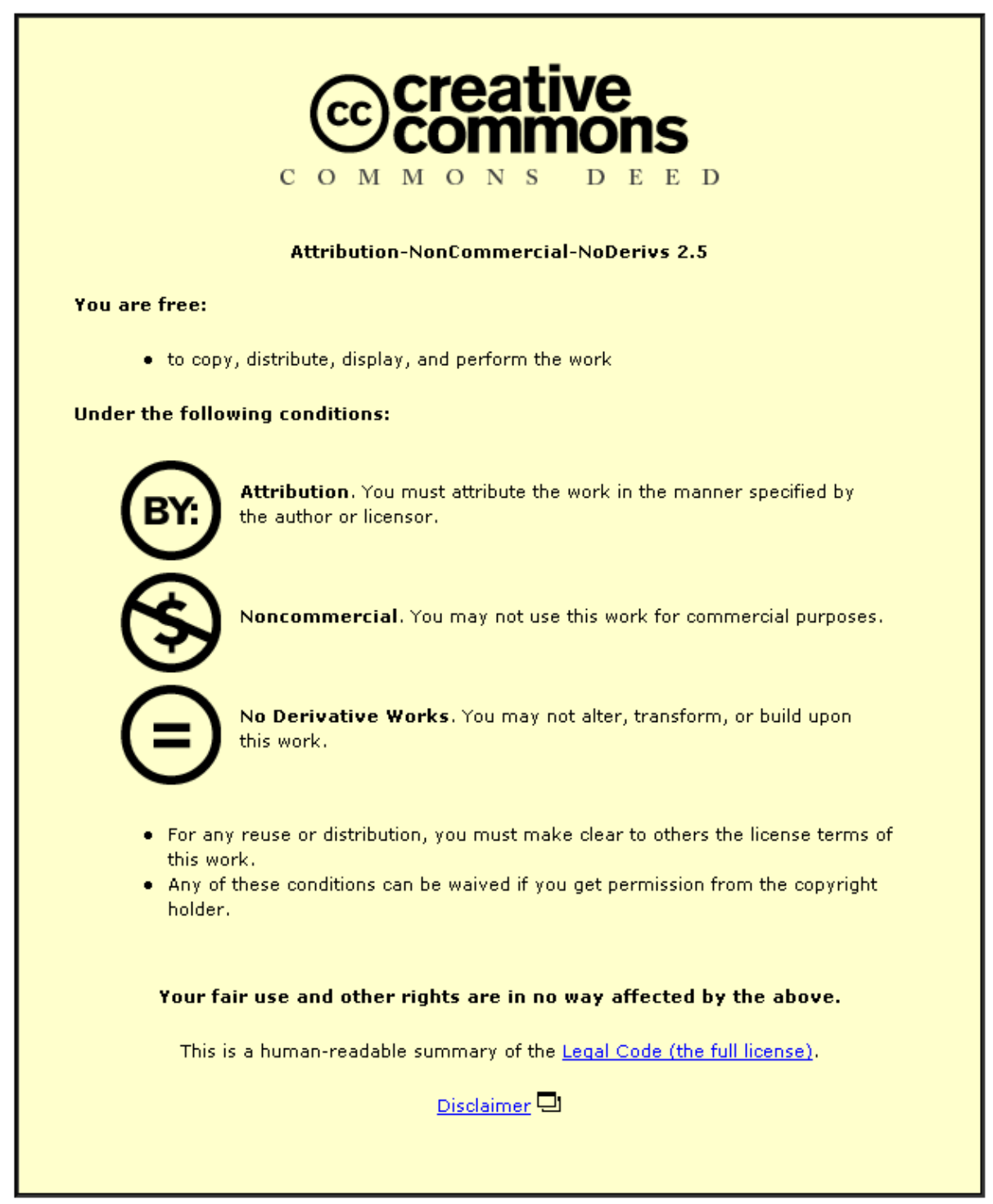

For the full text of this licence, please go to: http://creativecommons.org/licenses/by-nc-nd/2.5/ 


\section{Melt compounding of rigid PVC formulations with hydrotalcites}

\section{J. Hitt*, B. Haworth, N. L. Thomas and M. A. Algahtani}

Hydrotalcites, compounds of magnesium-aluminium-hydroxycarbonate, are promoted as environmentally safe materials for costabilisation of PVC products. Commercial grades of hydrotalcites have been added to rigid PVC formulations, containing a range of different stabiliser types, to evaluate their contribution to heat stability and their effect on mechanical properties. Hydrotalcites are confirmed to be effective costabilisers for rigid PVC: static thermal stability (through oven testing) and dynamic thermal stability (via torque rheometry) of PVC compounds are modified by their presence. The extent of change is determined by the primary stabiliser type and the grade of the hydrotalcite. Detailed analysis of mechanical properties has been carried out on compression moulded samples and on extruded compounds. With the former, no significant change in tensile or impact performance was observed, for hydrotalcite levels up to 5 phr. Charpy impact data on extruded PVC have shown significant increase in performance of compounds containing an acrylate modifier when hydrotalcites are used.

Keywords: PVC, Hydrotalcite, Processing, Thermal stability, Mechanical properties

\section{Introduction and objectives}

Over recent years attention has been paid to the use of synthetic hydrotalcites as stabilisers for PVC. Hydrotalcites are forms of hydrated magnesiumaluminium-hydroxycarbonates: a typical formula is $\mathrm{Mg}_{6} \mathrm{Al}_{2}(\mathrm{OH})_{16} \mathrm{CO}_{3} .4 \mathrm{H}_{2} \mathrm{O}$. The structure consists of layers of magnesium hydroxide and aluminium hydroxide with anionic interlayers comprising the carbonates and the bound water. The carbonate can be substituted with other anions, such as sulphates and nitrates, to form other hydrotalcite like layered double hydroxides (LDHs). It is the capacity of hydrotalcites for anionic exchange that makes the materials highly suited to the task of stabilising PVC. Papers on the use of hydrotalcites alone, and in combination with $\mathrm{CaZn}$, lead and tin stabilisers are now reviewed.

van der Ven et al. ${ }^{1}$ evaluated the stability of PVC with a range of hydrotalcite like materials of the general formula of $\mathrm{Mg}_{3} \mathrm{ZnAl}_{2}(\mathrm{OH})_{12}$. A. $n \mathrm{H}_{2} \mathrm{O}$ with different anions (A). They concluded that the stabilisation offered by hydrotalcites relates to the capacity of the materials to react with $\mathrm{HCl}$ formed during the degradation of PVC through a two step process: first, the interlayer anions react with $\mathrm{HCl}$ and second, the hydroxide layers are lost as these react with $\mathrm{HCl}$ to form metal chlorides.

Lin et al. ${ }^{2}$ drew the same conclusion as van der Ven et al., ${ }^{1}$ regarding the mechanism of stabilisation of $\mathrm{PVC}$, after testing compression moulded composites of calcium stearate/zinc stearate stabilised PVC-P with

IPTME, Loughborough University, Loughborough, LE11 3TU, UK

*Corresponding author, email d.j.hitt@lboro.ac.uk nanoparticles of hydrotalcite like $\mathrm{Mg}-\mathrm{Al}-\mathrm{CO}_{3} \mathrm{LDHs}$. They also reported that materials with a $\mathrm{Mg} / \mathrm{Al}$ ratio of 2 gave maximum enhancement of thermal stability and the optimum addition level appeared to be 2 phr. In a subsequent paper by Lin et al. ${ }^{3}$ modification of a $\mathrm{Mg}-$ $\mathrm{Zn}-\mathrm{Al}-\mathrm{CO}_{3}$ hydrotalcite by reaction with maleic acid produced a $\mathrm{Mg}-\mathrm{Zn}-\mathrm{Al}-$ maleate $\mathrm{LDH}$ with increased spacing between the hydroxide layers. PVC-P composites containing this intercalated structure also had greatly improved stability but to a much lesser extent than the $\mathrm{Mg}-\mathrm{Al}-\mathrm{CO}_{3} \mathrm{LDH}$.

The stabilisation of PVC by lead stearate in combination with hydrotalcite (Alcamizer 1) has been studied by Kalouskova et al. ${ }^{4} \mathrm{~A}$ range of PVC foils produced at $180^{\circ} \mathrm{C}$ were assessed by colour change at $180^{\circ} \mathrm{C}$ (oven test). As expected increasing the lead stearate content to $3 \mathrm{phr}$ progressively improved the thermal stability of the PVC, while, a stabiliser combination of $0.75 \mathrm{phr}$ of the stearate plus $2 \mathrm{phr}$ of the Alcamizer (i.e. a costabiliser system) performed even better. However, perhaps the most interesting result was the colour change comparison of the PVC without any stabiliser (initially red) and the PVC with $2 \mathrm{phr}$ of the hydrotalcite (initially clear/ pink). The former darkened to reddish/black over $65 \mathrm{~min}$, while the latter did the same over $70 \mathrm{~min}$, via a pink to orange to red sequence. This evidence showed the hydrotalcite only acts as a $\mathrm{HCl}$ acceptor and does not prevent (dis)colouration of the polymer.

Stabilisation of PVC by untreated and surface treated hydrotalcites in combination with organotin and lead stabilisers has also been reported. Evidence gathered from thermogravimetric analysis and ultraviolet spectra, but primarily from Congo red tests, 5,6 showed the stability of PVC was substantially improved by a 
combination of titanate treated hydrotalcite and tin stabiliser. It appeared that the optimum addition level for the hydrotalcite was $5 \%$ by weight. Injection moulding was used to produce notched Izod and tensile test pieces from compounds of PVC plus hydrotalcite. ${ }^{6}$ Izod impact strength, tensile strength and elongation at break all declined as the hydrotalcite content was increased to $10 \%$.

In some cases in the literature, researchers have used hydrotalcites synthesised in their own laboratories. However, for the work presented here, two commercial grades of hydrotalcites have been obtained: Alcamizer P93 from Kisuma Chemicals ${ }^{7}$ and Sorbacid 911 from Sud-Chemie. ${ }^{8}$ The materials are promoted as environmentally safe costabilisers for PVC, which contribute to excellent thermal stability, have excellent dispersability and are well suited to transparent applications.

In this study, hydrotalcites have been processed via two routes after dry blending of rigid PVC formulations: mill mixing followed by compression moulding and by extrusion. In both cases processing conditions have been employed with the objective of generating products with levels of gelation associated with good mechanical strength. (Rather than minimise thermal history that might exaggerate thermal stability.) As the commercial grades are considered to be ultrafine, majority of particles smaller than $1 \mu \mathrm{m}$, effective dispersion of the particles ought to produce good mechanical strength in tandem with the anticipated enhancement of both dynamic and thermal stability.

\section{Experimental}

\section{Materials and processing conditions Hydrotalcites}

Table 1 gives details of the two grades of hydrotalcite used in this work.

\section{Sample preparation by compressing moulding}

The hydrotalcites were added to PVC formulations containing tin and $\mathrm{CaZn}$ stabilisers, and an organic based stabiliser (OBS). The formulations (Table 2) were blended at $3500 \mathrm{rev} \mathrm{min}^{-1}$ (to a discharge temperature of $120^{\circ} \mathrm{C}$ ) using a Henschel FML 10 laboratory scale high speed mixer. Dry blends were mixed further on a two roll mill at $155^{\circ} \mathrm{C}$ for tin stabilised and hydrotalcite only formulations and at $165^{\circ} \mathrm{C}$ for $\mathrm{CaZn}$ and $\mathrm{OBS}$ formulations. Compression moulded sheets, of nominally 1 or $1.5 \mathrm{~mm}$ thickness, were produced from the milled sheets at $195^{\circ} \mathrm{C}$.

\section{Preparation of extrudates}

The core content of all formulations comprised PVC (INEOS ChlorVinyls K68), stabiliser (Chemson PWX15840), processing aid (Rohm and Haas Paraloid $\mathrm{K} 120 \mathrm{~N}$ ) and titanium dioxide (Kronos 2220). An impact modifier (Rohm and Haas KM 355) and the hydrotalcites were added to the 'core' formulation as listed in Table 3, where each formulation has been assigned an identifier. All formulations were dry blended as stated earlier. Blends were processed using a Krauss Maffei KMD 2-25KK laboratory twin screw extruder fitted with a slot die (dimensions of the slot were $30 \times 5 \mathrm{~mm}$ ). The screw speed and screw temperature were respec-

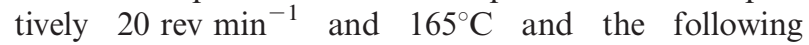
temperature profile was employed:

\begin{tabular}{llll}
\hline Barrel zone 1 & Barrel zone 2 & Adaptor & Die \\
$180^{\circ} \mathrm{C}$ & $190^{\circ} \mathrm{C}$ & $190^{\circ} \mathrm{C}$ & $200^{\circ} \mathrm{C}$ \\
\hline
\end{tabular}

\section{Thermal stability and characterisation Dry blends}

The dynamic stability of dry blends was evaluated using a Haake Rheocord 90. The chamber was set at $190^{\circ} \mathrm{C}$, the rotor speed was $60 \mathrm{rev} \mathrm{min}^{-1}$ and the batch weight $60 \mathrm{~g}$. After loading the chamber, the torque versus time curve initially shows two peaks: the first for compaction of the blend and the second when the blend has gelled. After this, the torque falls and levels out to a steady value. The subsequent increase in torque arises due to degradation of the melt. In this study, three values were derived from the torque-time curves: the time to the gelation peak, the equilibrium torque and the 'stability time': the interval between the time to the gelation peak and the onset of degradation.

\section{Products}

Thermal stability of products was assessed quantitatively from colour changes arising from oven heating of products at $190^{\circ} \mathrm{C}$ over a range of regular time intervals. Gelation was determined using a TA Instruments 2010

Table 1 Properties of hydrotalcites ${ }^{7-10}$

\begin{tabular}{lll}
\hline Grade & Alcamizer P93 & Sorbacid 911 \\
Supplier & Kisuma Chemicals & Sud-Chemie \\
Appearance & White powder & White powder \\
Chemical nature & Hydrated magnesium zinc & Hydrated magnesium \\
& aluminium hydroxycarbonate & aluminium hydroxycarbonate \\
Particles $>5 \mu \mathrm{m}$ & None & None \\
Particles $<1 \mu \mathrm{m}$ & $82 \%$ & Not specified \\
Average particle size, $\mu \mathrm{m}$ & $0 \cdot 7$ & $50 \%$ \\
\hline
\end{tabular}

Table 2 PVC formulations for compression moulding

\begin{tabular}{|c|c|c|c|c|c|}
\hline Component & Supplier/grade & phr & phr & phr & phr \\
\hline PVC resin & INEOS ChlorVinyls EVIPOL SH6830 & $100 \cdot 0$ & $100 \cdot 0$ & $100 \cdot 0$ & $100 \cdot 0$ \\
\hline Hydrotalcites & As Table 1 & 5 & $0-10$ & $0-5$ & $0-5$ \\
\hline CaZn stabiliser & Chemson PWX15840 (one pack) & & $4 \cdot 5$ & & \\
\hline OBS & Chemson PWX15861 & & & 4 & \\
\hline Tin stabiliser & Akcros BTS71 & & & & 2 \\
\hline
\end{tabular}


differential scanning calorimeter, where samples of $15 \mathrm{mg}$ were heated from ambient temperature to $240^{\circ} \mathrm{C}$ under a controlled rate of $20^{\circ} \mathrm{C} \mathrm{min}^{-1}$. Reflectance mode X-ray diffraction patterns, over the range of $2 \theta=5$ to $50^{\circ}$, were obtained using a Bruker D8 X-ray diffractometer with a $\mathrm{Cu} K_{\alpha}$ source. Images of sections through samples were taken with a JEOL 2000FX TEM at $200 \mathrm{kV}$.

\section{Mechanical properties Tensile testing}

For both compression moulded and extruded products a template was used to cut dumbbell shaped tensile testpieces with overall dimensions of $100 \times 12.5 \mathrm{~mm}$ with a waisted section of $30 \mathrm{~mm}$ gauge length by $4.4 \mathrm{~mm}$ width. Tests were carried out at $10 \mathrm{~mm} \mathrm{~min}^{-1}$ on a Hounsfield tensometer fitted with $1 \mathrm{kN}$ load cell for moulded samples and $10 \mathrm{kN}$ for extruded products. For a given product at least six samples were tested.

\section{Impact testing of mouldings}

A Rosand instrumented falling weight impact tester was used to test the compression mouldings. A $10 \mathrm{~mm}$ diameter hemispherical tipped striker attached to a $10 \mathrm{~kg}$ mass was dropped from a height of $1 \mathrm{~m}$ giving an impact velocity of $4.4 \mathrm{~m} \mathrm{~s}^{-1}$ and impact energy of $98 \mathrm{~J}$. From the load deflection curve, three properties were derived: peak force, peak energy and failure energy (peak energy plus energy required for striker to completely penetrate the sample). Six samples of a given product were tested.

\section{Impact testing of extrudates}

For extruded products, Charpy samples (type A with notch tip radius of $0.25 \mathrm{~mm}$ ) were prepared in accordance with BS ENO 179-1:2001. These were tested using a RAY-RAN universal pendulum impact tester fitted with a standard hammer that struck samples at
$3 \cdot 8 \mathrm{~m} \mathrm{~s}^{-1}$ with an energy of $7 \cdot 5 \mathrm{~J}$. For each extrudate batches of 10 or 15 samples were prepared.

\section{Results and discussion}

In the data tables of mechanical properties presented in this section, calculated average values are given with standard deviations in brackets. Also, the results on OBS formulations in Tables 4-6 and in Fig. 1 were drawn from work by Algahtani. ${ }^{11}$ Measurements obtained by differential scanning calorimetry (DSC) will not be included in the results here. However, a number of comments on the data are included. Differential scanning calorimetry showed that the level of gelation in compression moulded samples was good with the enthalpy of the melt endotherm being consistent across the range of stabiliser types: typically 4-5 $\mathrm{J} \mathrm{g}^{-1}$. It also confirmed that the actual compression moulding temperature was close to $195^{\circ} \mathrm{C}$. Differential scanning calorimetry analysis of the extrudates was also reasonably consistent (melt enthalpies of 3.5-4.5 $\mathrm{J} \mathrm{g}^{-1}$ ) and showed the processing temperature to be $\sim 194$ $196^{\circ} \mathrm{C}$. The derivation of enthalpy associated with melt endotherm and processing temperature from DSC curves is well established. ${ }^{12-14}$

At this point it is appropriate to make some observations upon the two formulations of PVC plus $5 \mathrm{phr}$ of each hydrotalcite. When the hydrotalcite only blends were milled the banded sheet initially appeared to be clear. However, as milling continued the sheet turned pink, which darkened to red by the end of the mill mixing regime. Compression moulding of the milled products generated sheets that were very dark red in colour. This sequence of colour changes can be seen to some extent, and almost identically, in the respective thermal stability charts of Lin et $a l^{3}$ and of Kalouskova. ${ }^{4}$ Colour change is one of the most

Table 3 Formulations for extrusion

\begin{tabular}{|c|c|c|c|c|c|c|c|c|c|c|}
\hline & phr & phr & phr & phr & phr & phr & phr & phr & phr & phr \\
\hline PVC resin & $100 \cdot 0$ & $100 \cdot 0$ & $100 \cdot 0$ & $100 \cdot 0$ & $100 \cdot 0$ & $100 \cdot 0$ & $100 \cdot 0$ & $100 \cdot 0$ & $100 \cdot 0$ & $100 \cdot 0$ \\
\hline CaZn stabiliser & $4 \cdot 5$ & 4.5 & 4.5 & $4 \cdot 5$ & $4 \cdot 5$ & $4 \cdot 5$ & $4 \cdot 5$ & $4 \cdot 5$ & $4 \cdot 5$ & $4 \cdot 5$ \\
\hline Processing aid & $1 \cdot 0$ & $1 \cdot 0$ & $1 \cdot 0$ & $1 \cdot 0$ & $1 \cdot 0$ & $1 \cdot 0$ & $1 \cdot 0$ & $1 \cdot 0$ & $1 \cdot 0$ & $1 \cdot 0$ \\
\hline Titanium dioxide & $4 \cdot 0$ & $4 \cdot 0$ & $4 \cdot 0$ & $4 \cdot 0$ & $4 \cdot 0$ & $4 \cdot 0$ & $4 \cdot 0$ & $4 \cdot 0$ & $4 \cdot 0$ & $4 \cdot 0$ \\
\hline Impact modifier & & $7 \cdot 0$ & $7 \cdot 0$ & $7 \cdot 0$ & $7 \cdot 0$ & & $4 \cdot 0$ & $7 \cdot 0$ & $7 \cdot 0$ & $7 \cdot 0$ \\
\hline Alcamizer P93 & & & $2 \cdot 0$ & $5 \cdot 0$ & $10 \cdot 0$ & $5 \cdot 0$ & $5 \cdot 0$ & & & \\
\hline Sorbacid 911 & & & & & & & & $2 \cdot 0$ & $5 \cdot 0$ & $10 \cdot 0$ \\
\hline IDENTIFIER & CORE & REF & $2 \mathrm{~A} / 7 \mathrm{M}$ & $5 \mathrm{~A} / 7 \mathrm{M}$ & $10 \mathrm{~A} / 7 \mathrm{M}$ & $5 \mathrm{~A} / 0 \mathrm{M}$ & $5 \mathrm{~A} / 4 \mathrm{M}$ & $2 \mathrm{~S} / 7 \mathrm{M}$ & $5 S / 7 M$ & $10 S / 7 M$ \\
\hline
\end{tabular}

Table 4 Torque rheometry data for 'compression moulding' formulations

\begin{tabular}{|c|c|c|c|c|c|c|}
\hline $\begin{array}{l}\text { Hydrotalcite, } \\
\text { phr }\end{array}$ & $\begin{array}{l}\text { Time to gelation } \\
\text { peak, min }\end{array}$ & $\begin{array}{l}\text { Equilibrium } \\
\text { torque, } \\
\mathrm{Nm}\end{array}$ & $\begin{array}{l}\text { Stability time, } \\
\text { min }\end{array}$ & $\begin{array}{l}\text { Time to } \\
\text { gelation } \\
\text { peak, min }\end{array}$ & $\begin{array}{l}\text { Equilibrium } \\
\text { torque, Nm }\end{array}$ & $\begin{array}{l}\text { Stability } \\
\text { time, min }\end{array}$ \\
\hline & \multicolumn{3}{|l|}{ Alcamizer P93 } & \multicolumn{3}{|c|}{ Sorbacid 911} \\
\hline \multirow[t]{2}{*}{5} & $2 \cdot 2$ & $18 \cdot 5$ & $3 \cdot 7$ & $2 \cdot 2$ & $18 \cdot 7$ & $3 \cdot 6$ \\
\hline & \multicolumn{3}{|l|}{ Tin + Alcamizer P93 } & \multicolumn{3}{|c|}{ Tin + Sorbacid 911} \\
\hline 0 & $1 \cdot 0$ & $13 \cdot 7$ & $6 \cdot 6$ & $1 \cdot 0$ & $13 \cdot 7$ & $6 \cdot 6$ \\
\hline \multirow[t]{2}{*}{5} & $1 \cdot 6$ & $16 \cdot 5$ & $3 \cdot 8$ & $1 \cdot 2$ & $15 \cdot 5$ & $7 \cdot 3$ \\
\hline & \multicolumn{3}{|c|}{ CaZn+Alcamizer P93 } & \multicolumn{3}{|c|}{ CaZn+Sorbacid 911} \\
\hline 0 & $2 \cdot 8$ & $15 \cdot 1$ & $4 \cdot 6$ & $2 \cdot 8$ & $15 \cdot 1$ & $4 \cdot 6$ \\
\hline 2 & $2 \cdot 8$ & $14 \cdot 2$ & $10 \cdot 5$ & $2 \cdot 2$ & $14 \cdot 4$ & $12 \cdot 6$ \\
\hline \multirow[t]{2}{*}{5} & $1 \cdot 8$ & $14 \cdot 1$ & $13 \cdot 0$ & $1 \cdot 6$ & $14 \cdot 1$ & $13 \cdot 2$ \\
\hline & \multicolumn{3}{|l|}{ OBS + Alcamizer P93 } & \multicolumn{3}{|c|}{ OBS + Sorbacid 911} \\
\hline 0 & $1 \cdot 8$ & $15 \cdot 4$ & $8 \cdot 1$ & $1 \cdot 8$ & $15 \cdot 4$ & $8 \cdot 1$ \\
\hline 2 & $2 \cdot 0$ & $14 \cdot 9$ & $11 \cdot 2$ & 1.5 & $15 \cdot 1$ & $10 \cdot 7$ \\
\hline 5 & $1 \cdot 8$ & $15 \cdot 2$ & $11 \cdot 5$ & 2.0 & $15 \cdot 5$ & $11 \cdot 2$ \\
\hline
\end{tabular}




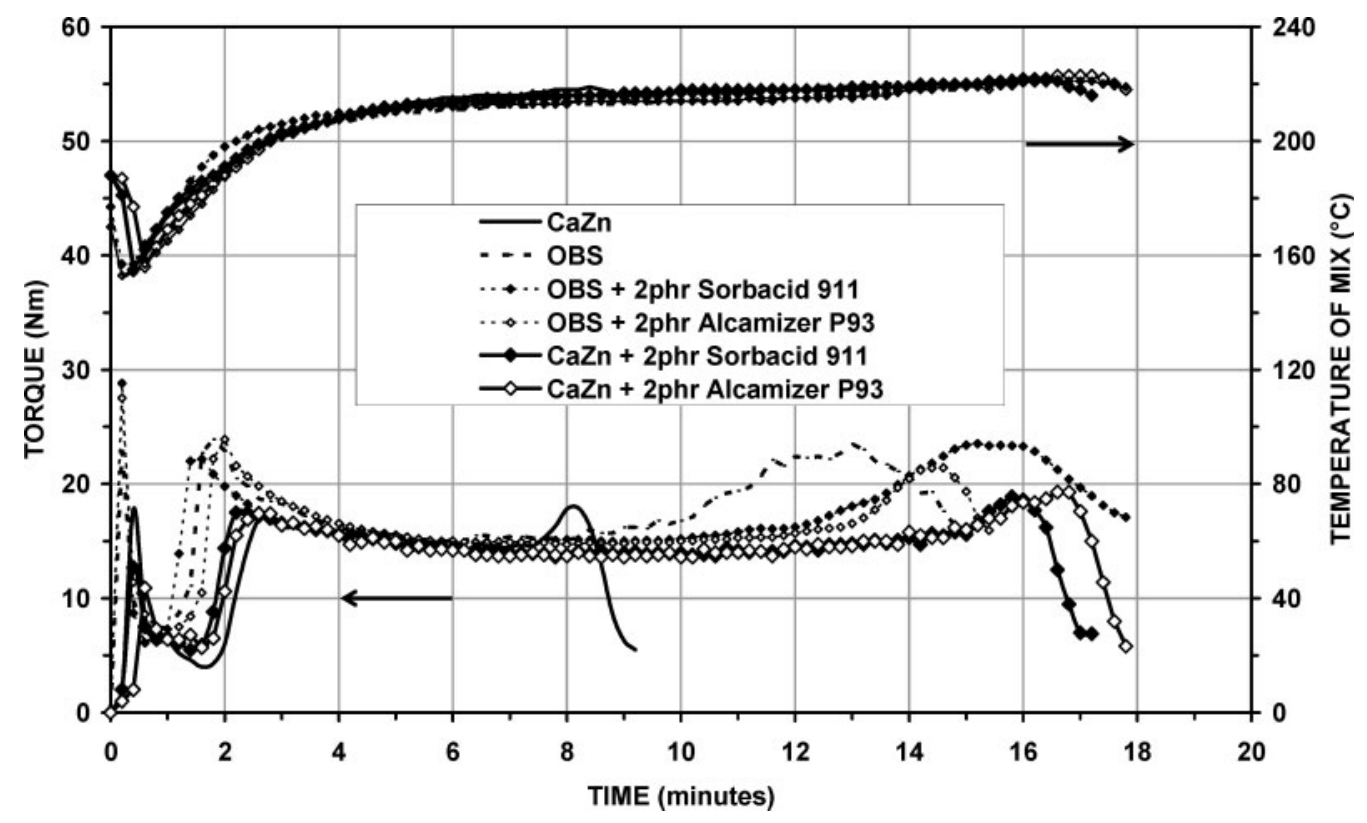

\section{Effect on dynamic stability of adding 2 phr of hydrotalcite}

apparent indicators of degradation of PVC and the sequence is often seen as yellow to reddish brown and ultimately to black. In some studies this progression in colour has been attributed to the formation of strongly coloured carbonium salts. ${ }^{15}$ However, it is more commonly attributed to the conjugated double bonds that arise from dehydrochlorination, where polyene sequences of just seven conjugated double bonds can cause PVC to change colour, and sequences of up to 30 have been found in the course of the process. ${ }^{15}$ Thus, it appears in the presence of hydrotalcites only, particular polyene sequences are generated during degradation that give rise to the observed colour changes. It should also be noted that the extent of degradation to cause colour

Table 5 Tensile properties of compression mouldings

\begin{tabular}{|c|c|c|c|c|c|c|}
\hline $\begin{array}{l}\text { Hydrotalcite, } \\
\text { phr }\end{array}$ & $\begin{array}{l}\text { Yield strength, } \\
\mathrm{MPa}\end{array}$ & $\begin{array}{l}\text { Strength } \\
\text { at break, } \mathrm{MPa}\end{array}$ & $\begin{array}{l}\text { Elongation } \\
\text { at break, \% }\end{array}$ & $\begin{array}{l}\text { Yield strength, } \\
\mathrm{MPa}\end{array}$ & $\begin{array}{l}\text { Strength } \\
\text { at break, } \mathrm{MPa}\end{array}$ & $\begin{array}{l}\text { Elongation } \\
\text { at break, \% }\end{array}$ \\
\hline & \multicolumn{3}{|l|}{ Alcamizer P93 } & \multicolumn{3}{|l|}{ Sorbacid 911} \\
\hline \multirow[t]{2}{*}{5} & $51.6(0.2)$ & $52.0(1.5)$ & $154 \cdot 0(14 \cdot 0)$ & $51.8(0.5)$ & $51 \cdot 0(1 \cdot 7)$ & $149 \cdot 3(10 \cdot 1)$ \\
\hline & \multicolumn{3}{|c|}{ Tin +Alcamizer P93 } & \multicolumn{3}{|c|}{ Tin + Sorbacid 911} \\
\hline 0 & $58 \cdot 1(1.9)$ & $53 \cdot 3(5 \cdot 0)$ & $163.0(15.5)$ & $58 \cdot 1(1.9)$ & $53.3(5 \cdot 0)$ & $163.0(15.5)$ \\
\hline \multirow[t]{2}{*}{5} & $56.5(1.7)$ & $54.8(4.9)$ & $178.7(19.9)$ & $56 \cdot 6(2 \cdot 0)$ & $53.2(3.5)$ & $165 \cdot 8(21 \cdot 8)$ \\
\hline & \multicolumn{3}{|c|}{ CaZn+Alcamizer P93 } & \multicolumn{3}{|c|}{ CaZn + Sorbacid 911} \\
\hline 0 & $52 \cdot 5(1 \cdot 0)$ & $51.9(3.0)$ & $152 \cdot 6(13 \cdot 6)$ & $52 \cdot 5(1 \cdot 0)$ & $51.9(3.0)$ & $152 \cdot 6(13 \cdot 6)$ \\
\hline 2 & $52.5(1.0)$ & $53.7(4.9)$ & $153 \cdot 8(27 \cdot 3)$ & $50 \cdot 1(1 \cdot 1)$ & $50 \cdot 0(2.5)$ & $143.0(9 \cdot 0)$ \\
\hline 5 & $49 \cdot 1(1 \cdot 3)$ & $50 \cdot 1(3 \cdot 4)$ & $154.9(16 \cdot 3)$ & $48 \cdot 7(1 \cdot 7)$ & $50 \cdot 3(3 \cdot 4)$ & $154.8(14.9)$ \\
\hline \multirow[t]{2}{*}{10} & $47 \cdot 0(0 \cdot 8)$ & $51 \cdot 1(1 \cdot 2)$ & $175 \cdot 0(5 \cdot 6)$ & $46.5(0.8)$ & $48.7(3.0)$ & $156 \cdot 4(21 \cdot 2)$ \\
\hline & \multicolumn{3}{|c|}{ OBS + Alcamizer P93 } & \multicolumn{3}{|c|}{ OBS + Sorbacid 911} \\
\hline 0 & $51 \cdot 1(3 \cdot 2)$ & $53.0(5 \cdot 3)$ & $170 \cdot 0(19 \cdot 7)$ & $51 \cdot 1(3 \cdot 2)$ & $53.0(5 \cdot 3)$ & $170 \cdot 0(19 \cdot 7)$ \\
\hline 2 & $50 \cdot 5(1.3)$ & $55 \cdot 7(2 \cdot 1)$ & $181 \cdot 0(10 \cdot 7)$ & $51.0(1.0)$ & $53.3(3.0)$ & $164 \cdot 7(13 \cdot 0)$ \\
\hline 5 & $48.8(0.4)$ & $54.6(2 \cdot 4)$ & $183.3(11.3)$ & $48.8(0.6)$ & $46 \cdot 4(7 \cdot 4)$ & $124.0(53.3)$ \\
\hline
\end{tabular}

Table 6 Instrumented falling weight impact tester data for compression moulded samples*

\begin{tabular}{|c|c|c|c|c|c|c|}
\hline $\begin{array}{l}\text { Hydrotalcite, } \\
\text { phr }\end{array}$ & $\begin{array}{l}\text { Peak force, } \\
\mathrm{N} \mathrm{mm}^{-1}\end{array}$ & $\begin{array}{l}\text { Peak energy, } \\
\mathrm{J} \mathrm{mm}^{-1}\end{array}$ & $\begin{array}{l}\text { Failure energy, } \\
\mathrm{J} \mathrm{mm}^{-1}\end{array}$ & $\begin{array}{l}\text { Peak force, } \\
\mathrm{Nm} \mathrm{m}^{-1}\end{array}$ & $\begin{array}{l}\text { Peak energy, } \\
\mathrm{J} \mathrm{mm}^{-1}\end{array}$ & $\begin{array}{l}\text { Failure energy, } \\
\mathrm{J} \mathrm{mm}^{-1}\end{array}$ \\
\hline & \multicolumn{3}{|c|}{ Tin+Alcamizer P93 } & \multicolumn{3}{|c|}{ Tin + Sorbacid 911} \\
\hline 0 & D 1363 (39) & $7.19(0.53)$ & $11.80(0.49)$ & D 1363 (39) & $7.19(0.53)$ & $11.80(0.49)$ \\
\hline \multirow[t]{2}{*}{5} & D $1363(27)$ & $7.28(0.32)$ & $12.03(0.40)$ & D 1366 (16) & $7 \cdot 40(0.15)$ & $12 \cdot 14(0 \cdot 13)$ \\
\hline & \multicolumn{3}{|c|}{ CaZn+Alcamizer P93 } & \multicolumn{3}{|c|}{ CaZn + Sorbacid 911} \\
\hline 0 & D $1363(32)$ & $6.98(0.30)$ & $11.30(0.32)$ & D $1363(32)$ & $6.98(0.30)$ & $11.30(0.32)$ \\
\hline 5 & M $1321(24)$ & $6.70(0.72)$ & $10.41(0.93)$ & M $1318(21)$ & $6.98(0.53)$ & $10 \cdot 73(0.83)$ \\
\hline \multirow[t]{2}{*}{10} & B 1254 (183) & $6 \cdot 20(1.72)$ & $9 \cdot 31(2 \cdot 20)$ & В 1292 (33) & $6.57(0.96)$ & $9.82(1.00)$ \\
\hline & \multicolumn{3}{|c|}{ OBS + Alcamizer P93 } & \multicolumn{3}{|c|}{ OBS + Sorbacid 911} \\
\hline 0 & D $1430(25)$ & $7 \cdot 40(0.17)$ & $11 \cdot 50(0.21)$ & D $1430(25)$ & $7 \cdot 40(0 \cdot 17)$ & $11 \cdot 50(0 \cdot 21)$ \\
\hline 2 & D 1446 (44) & $7.30(0.81)$ & $11.00(0.61)$ & D $1432(18)$ & $7.40(0.28)$ & $11 \cdot 10(0.28)$ \\
\hline 5 & D 1403 (33) & $7.40(0.18)$ & $10 \cdot 70(0 \cdot 18)$ & M 1428 (37) & $7.30(0.59)$ & $10.60(0.52)$ \\
\hline
\end{tabular}

*Letters in peak force boxes denote mode of failure: D - all failures were ductile (sample punctured), B - all failures were brittle (sample shattered) and $\mathrm{M}-$ mixture of $\mathrm{D}$ and $\mathrm{B}$. 


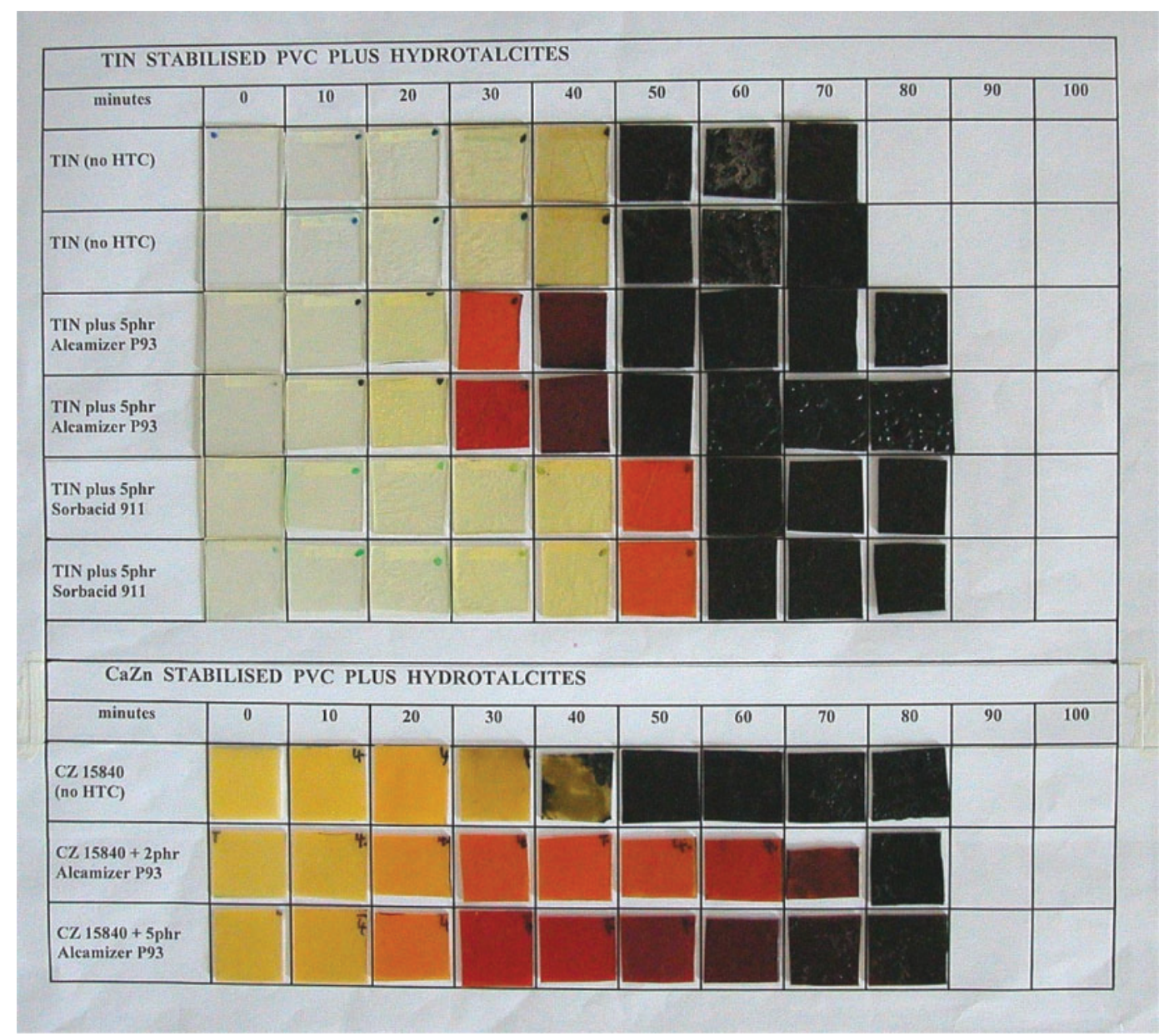

\section{Oven stability chart for PVC formulations}

change is very low: a loss of mass of just $0 \cdot 1 \%$ from $\mathrm{PVC}$, by dehydrochlorination, is enough. ${ }^{16}$

\section{Torque rheometry and dynamic stability}

In Table 4 hydrotalcites, in combination with the tin stabiliser, appear to have a mixed effect: stability time is significantly reduced with Alcamizer, but improved with Sorbacid. In fact, the stability time for tin with Alcamizer is little different from the Alcamizer only formulation. This might be related to the increased torque on adding the Alcamizer to the tin stabilised formulation, however, adding Sorbacid to the tin stabilised formulation also increases torque but still improved stability time. For the CaZn stabiliser, adding $2 \mathrm{phr}$ of hydrotalcite greatly increases stability time, which is further increased at $5 \mathrm{phr}$ of the additive. Similar trends, but less pronounced, are found on adding hydrotalcite to the OBS formulation.

Figure 1 shows the effect of adding 2 phr of hydrotalcite to $\mathrm{CaZn}$ and OBS formulations. The curves illustrate how hydrotalcites do not significantly affect equilibrium torque or change the temperature reached by the mix.

\section{Thermal (oven) stability}

An oven stability chart is shown in Fig. 2 for sets of samples cut from compression mouldings of three formulations: tin stabilised and similar tin stabilised plus 5 phr Alcamizer or Sorbacid. The chart shows that in terms of stability the formulations can be ranked: tin + Sorbacid $>$ tin only $>$ tin + Alcamizer. This is in complete agreement with the torque rheometer data. Another significant feature is the sequence of colours observed. For tin only the sequence is clear to yellow to black. With the hydrotalcites this sequence is punctuated by the appearance of orange and dark red coloured samples, at 30 and $40 \mathrm{~min}$ respectively with the Alcamizer, and by orange coloured samples at $50 \mathrm{~min}$ with the Sorbacid.

Oven stability tests for hydrotalcites in combination with the CaZn stabiliser and the OBS also agreed with the dynamic stability results. In both cases, the time at which the samples ultimately went black was substantially delayed by adding hydrotalcites. In terms of time to initial colour change the OBS only formulation changed well before the formulations of OBS with hydrotalcites. However, with CaZn, the first formulations to show colour change were those with $5 \mathrm{phr}$ hydrotalcite, while the three formulations of $\mathrm{CaZn}$ alone, and of CaZn with 2 phr of the hydrotalcites all seemingly began to discolour at about the same time. Figure 2 illustrates this for 2 and $5 \mathrm{phr}$ additions of Alcamizer. Thus, 2 phr of hydrotalcite in combination with $\mathrm{CaZn}$ offers both greatly improved dynamic stability and oven stability, but increasing the additive level to $5 \mathrm{phr}$, has additional benefit in terms of dynamic stability but seemingly reduces oven stability. Evaluation of the oven aged samples of CaZn and of CaZn plus 5 phr hydrotalcite by Raman spectroscopy confirmed that unsaturation of PVC chains increased in the presence of hydrotalcite. ${ }^{17}$ 


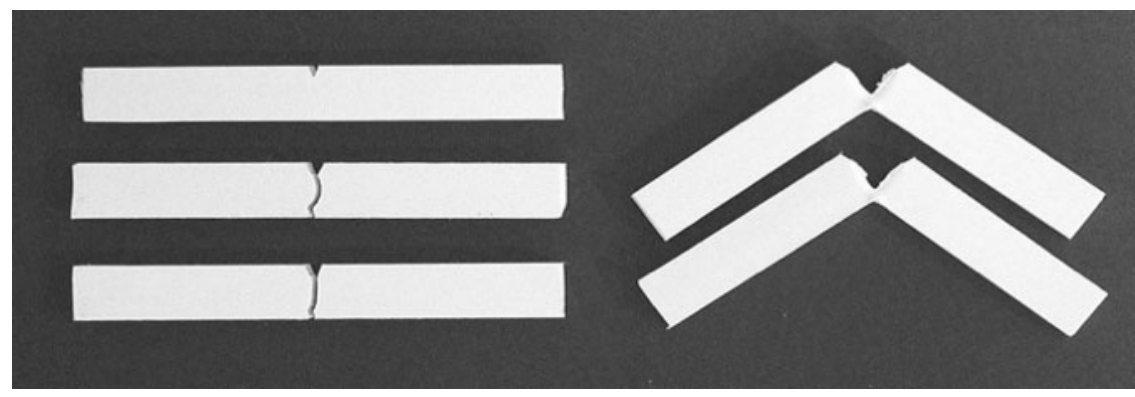

3 Notched Charpy sample with two examples of breaks and 'non-breaks'

\section{Mechanical properties of compression moulded samples \\ Tensile properties}

Table 5 shows that very good tensile properties are obtained for all formulations tested, even the highly discoloured red compression mouldings of PVC plus hydrotalcite alone. From the table it is clear that adding hydrotalcites reduces yield strength, but not greatly: at $5 \mathrm{phr}$ it is down by $2.6 \%$ with tin, by $\sim 7 \%$ with CaZn and by $4 \cdot 5 \%$ with OBS. Also, Alcamizer appears to have no detrimental effect upon properties at break, while $5 \mathrm{phr}$ of Sorbacid does significantly lower the break values when combined with OBS. A slight reduction of yield strength, if accompanied by increased elongation or ductility, is a desirable response that may have potential for impact modification and/or toughness enhancement.

\section{Impact properties}

These are presented in Table 6 for various formulations. The results correlate with the tensile properties, in that very good impact properties (especially those of peak force and peak energy) are seen across the table. It appears that adding $5 \mathrm{phr}$ of hydrotalcite has little effect on values of peak force and peak energy but does reduce failure energy where sample batches displayed a mix of ductile and brittle failures (denoted by ' $M$ ' in Table 6). For OBS in particular, with $5 \mathrm{phr}$ Alcamizer, impact properties are very good, as all samples failed in a ductile manner, whereas with 5 phr Sorbacid, a mix of ductile and brittle failures occurred, which resulted in a reduction in failure energy, which correlates with the relative low tensile properties at break seen in Table 5 .

Overall, adding hydrotalcites up to $5 \mathrm{phr}$ does not appear to have any detrimental effect on the mechanical performance of compression moulded PVC. The evidence for CaZn plus 10 phr of hydrotalcite is that this level of addition is too high as some significant loss of both tensile strength and impact strength occurs.

\section{Mechanical properties of extrudates}

Properties of the extrudates are given in Table 7. For ease of comparison, the data have been divided into three sets and the results for two formulations, 'REF' (no hydrotalcite and $7 \mathrm{phr}$ impact modifier) and '5A/ 7M' (5 phr Alcamizer and $7 \mathrm{phr}$ impact modifier) appear twice. Table 7 shows that tensile properties are consistently good for all formulations, while notched Charpy impact strengths show substantial variations.

\section{Tensile properties}

Sets 1 and 3 show that adding hydrotalcite up to $10 \mathrm{phr}$ has little influence on yield strength, while properties at break show some slight variations, but with no real pattern. In Set 2, it is very apparent that an initial addition of Alcamizer at $5 \mathrm{phr}$, followed by increasing the impact modifier content, reduces yield strength, and it is only with the ' $5 \mathrm{~A} / 7 \mathrm{M}$ ' formulation that strength at break is affected.

\section{Notched Charpy impact strength}

Figure 3 illustrates the appearance of samples after impact testing and in Table 7 the number of breaks and

Table 7 Tensile properties and notched Charpy impact strength of extrudates

\begin{tabular}{|c|c|c|c|c|c|c|}
\hline \multirow[b]{2}{*}{ Identifier } & \multicolumn{3}{|l|}{ Tensile } & \multicolumn{3}{|c|}{ Notched Charpy impact } \\
\hline & $\begin{array}{l}\text { Yield strength, } \\
\mathrm{MPa}\end{array}$ & $\begin{array}{l}\text { Strength } \\
\text { at break, } \\
\mathrm{MPa}\end{array}$ & $\begin{array}{l}\text { Elongation } \\
\text { at break, \% }\end{array}$ & $\begin{array}{l}\text { No. of } \\
\text { breaks }\end{array}$ & $\begin{array}{l}\text { No.of } \\
\text { non-breaks }\end{array}$ & $\begin{array}{l}\text { 'Energy absorbed', } \\
\text { kJ m } \text { ' }^{-2}\end{array}$ \\
\hline \multicolumn{7}{|l|}{ Set 1} \\
\hline REF & $43.8(0.5)$ & $42 \cdot 3(4 \cdot 0)$ & $112 \cdot 3(32 \cdot 1)$ & 13 & 1 & $38.7(27 \cdot 8)$ \\
\hline $2 \mathrm{~A} / 7 \mathrm{M}$ & $44.0(1 \cdot 4)$ & $48.6(2.9)$ & $159 \cdot 3(19 \cdot 7)$ & 2 & 12 & $124 \cdot 2(27 \cdot 4)$ \\
\hline $5 \mathrm{~A} / 7 \mathrm{M}$ & $43.9(0.6)$ & $43.0(4 \cdot 1)$ & $139.5(26 \cdot 2)$ & 0 & 15 & $139.2(9 \cdot 7)$ \\
\hline $10 \mathrm{~A} / 7 \mathrm{M}$ & $44 \cdot 1(2 \cdot 1)$ & $45 \cdot 1(3 \cdot 3)$ & $137.8(10.9)$ & 0 & 15 & $125 \cdot 7(16 \cdot 0)$ \\
\hline \multicolumn{7}{|l|}{ Set 2} \\
\hline CORE & $51 \cdot 3(0 \cdot 7)$ & $52 \cdot 8(3.6)$ & $129 \cdot 5(18 \cdot 1)$ & 10 & 0 & $7 \cdot 7(2 \cdot 7)$ \\
\hline $5 \mathrm{~A} / 0 \mathrm{M}$ & $49.9(0.4)$ & $51.9(3.4)$ & $139 \cdot 1(21 \cdot 1)$ & 10 & 0 & $13 \cdot 7(4 \cdot 2)$ \\
\hline $5 \mathrm{~A} / 4 \mathrm{M}$ & $46.4(0.6)$ & $53.0(3.2)$ & $165.8(13.9)$ & 10 & 0 & $42.6(25 \cdot 0)$ \\
\hline $5 \mathrm{~A} / 7 \mathrm{M}$ & $43.9(0.6)$ & $43.0(4 \cdot 1)$ & $139.5(26 \cdot 2)$ & 0 & 15 & $139 \cdot 2(9 \cdot 7)$ \\
\hline \multicolumn{7}{|l|}{ Set 3} \\
\hline REF & $43.8(0.5)$ & $42 \cdot 3(4 \cdot 0)$ & $112 \cdot 3(32 \cdot 1)$ & 13 & 1 & $38.7(27 \cdot 8)$ \\
\hline $2 S / 7 M$ & $44.0(0.6)$ & $41 \cdot 3(4 \cdot 8)$ & $86.3(35.9)$ & 3 & 7 & $63.3(48.4)$ \\
\hline $5 S / 7 M$ & $43.1(0.8)$ & $45.2(5.6)$ & $130.5(42 \cdot 6)$ & 0 & 10 & $146.5(10.0)$ \\
\hline $10 \mathrm{~S} / 7 \mathrm{M}$ & $41 \cdot 2(0.7)$ & $40.3(3.6)$ & $104.5(31.6)$ & 0 & 10 & $122 \cdot 0(13 \cdot 1)$ \\
\hline
\end{tabular}




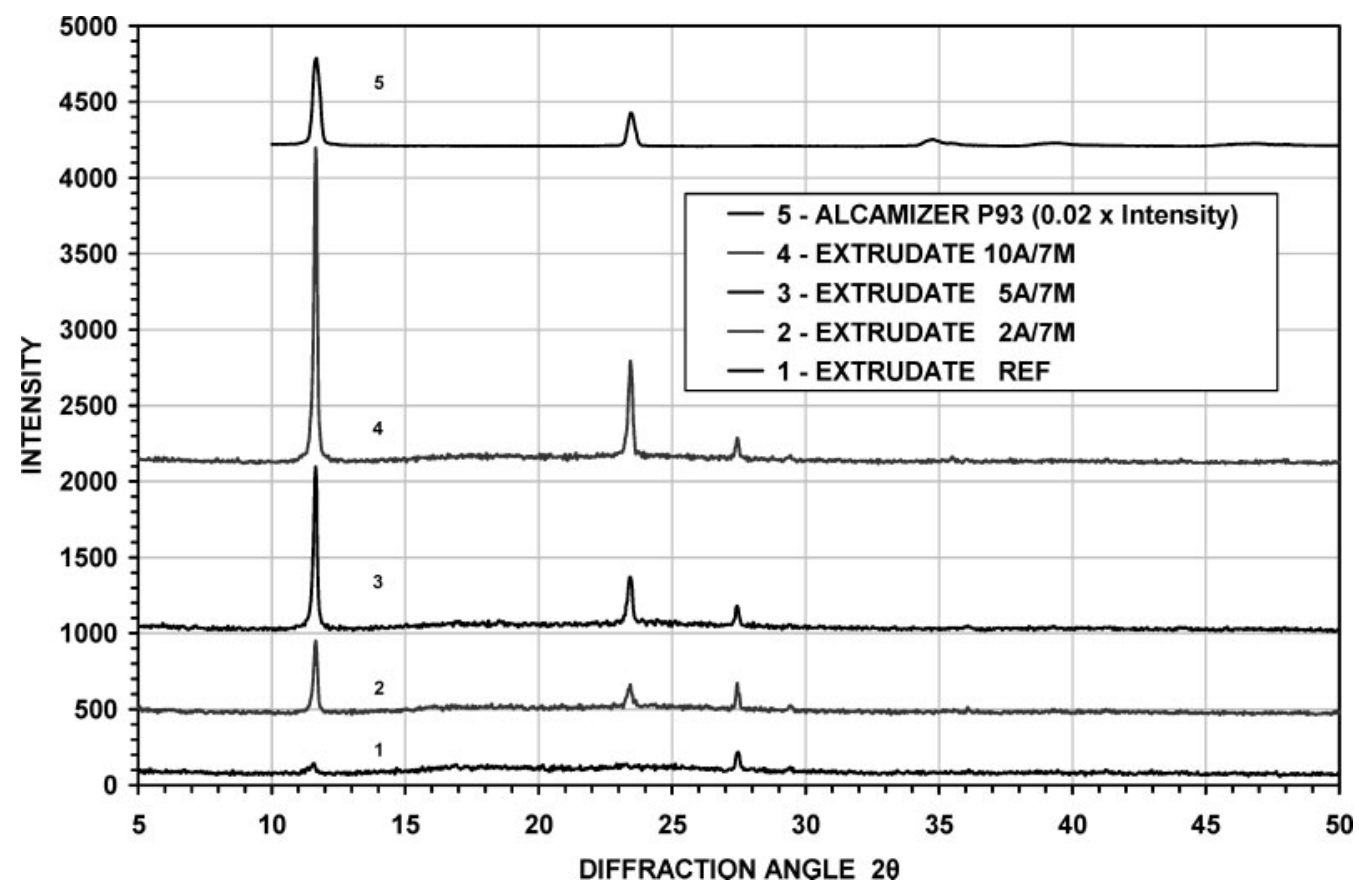

4 X-ray diffraction patterns for extrudates with different additions of Alcamizer

non-breaks is shown for each formulation. To compare impact strength, average values of 'energy absorbed' have been calculated for each formulation, whether the formulation gave $100 \%$ breaks, $100 \%$ non-breaks or a mixture of the two types of failure mode. Sets 1 and 3 show substantial increases in impact strength on adding 2 and $5 \mathrm{phr}$ of hydrotalcite. A further increase to $10 \mathrm{phr}$ of hydrotalcite reduces the enhancement in impact performance. In Set 2, adding $5 \mathrm{phr}$ of Alcamizer only to the core formulation does improve impact strength, however, only to a level that can be considered insignificant when compared to the reference formulation (Set 1). The introduction of impact modifier in Set 2 at $4 \mathrm{phr}$ gives an impact strength comparable to the reference formulation and at $7 \mathrm{phr}$ a substantial increase in impact strength is found.

Overall, very good tensile properties are found with all extrudates. In terms of impact performance, adding hydrotalcites in combination with an impact modifier can greatly improve notched impact strength. It would appear that this benefit can be accrued with $2 \mathrm{phr}$ of Alcamizer and maybe $3 \mathrm{phr}$ of Sorbacid.

\section{Characterisation of extrudates}

X-ray diffraction patterns are shown in Fig. 4. The top pattern $^{5}$ is that of Alcamizer alone, with its intensity scaled down considerably, to enable this pattern to be compared with those from extrudates. ${ }^{1-4}$ In the figure it is very evident that as the Alcamizer content of extrudate is increased, the main reflections of the hydrotalcite, at $2 \theta=11 \cdot 65$ and $23 \cdot 42^{\circ}$, increase accordingly. There are two other points to note. First, the lowest pattern, ${ }^{1}$ the reference formulation with no added hydrotalcite, has a small peak at $2 \theta=11 \cdot 65^{\circ}$ showing that some form of hydrotalcite is one of the components of the $\mathrm{CaZn}$ stabiliser one pack. Second, the reflection close to $2 \theta=27 \cdot 5^{\circ}$ arises from the titanium dioxide.

Transmission electron microscopy images, obtained from sections through the same set of extrudates displayed in Fig. 4, are shown in Fig. 5 (where the hydrotalcite particles have an elongated shape and titanium dioxide particles appear more circular as in the REF image in Fig. 5). The images confirm that the hydrotalcite, especially the fine particles, are well dispersed. It is this feature that produces the significant enhancement in impact strength.

\section{Conclusion}

Hydrotalcites are very effective costabilisers for PVC. The evidence presented here, on compression moulded samples, suggest that in combination with $\mathrm{CaZn}$ and
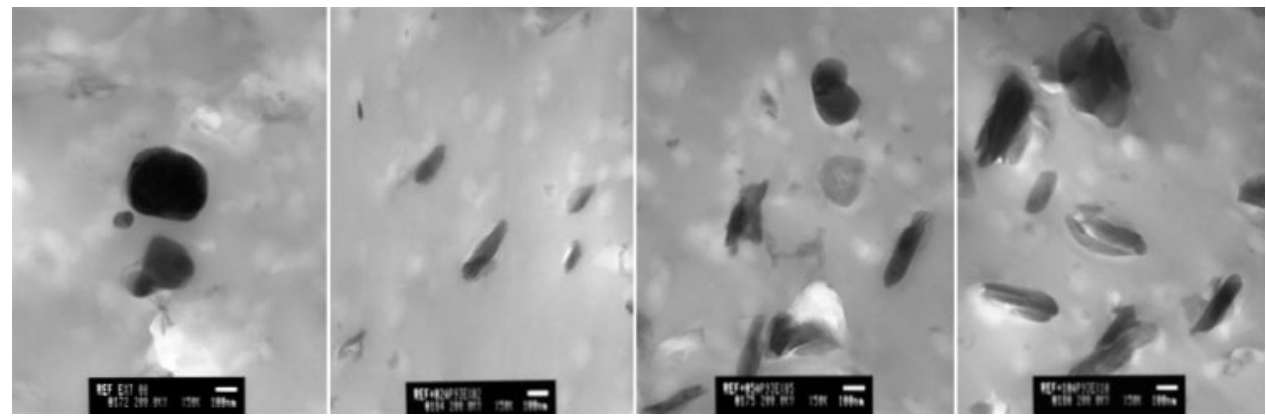

5 Transmission electron microscopy images of extrudates with different additions of Alcamizer: white bars equal $100 \mathrm{~nm}$ (from left to right: REF, $2 \mathrm{~A} / 7 \mathrm{M}, 5 \mathrm{~A} / 7 \mathrm{M}$ and $10 \mathrm{~A} / 7 \mathrm{M}$ ) 
OBS, as primary stabilisers, additive levels $\sim 2 \mathrm{phr}$ would be optimal. This level of addition has no detrimental effect upon mechanical performance. It is clear that in CaZn stabilised extrusion formulations, hydrotalcites (at 2-3 phr) act as reinforcing particles, as long as an impact modifier is present.

To follow on from these findings, research objectives are to:

(i) reevaluate the tin stabiliser but with hydrotalcites at 1 and $2 \mathrm{phr}$

(ii) assess the performance of extrudates costabilised with OBS and hydrotalcites (1, 2 and 5 phr)

(iii) further investigate the early stages of degradation of PVC formulations containing hydrotalcite by Raman spectroscopy.

It is also recognised that potential exists to further exploit the enhanced stability and mechanical properties offered by hydrotalcites by reducing particle size. Work on the synthesis of such hydrotalcites is currently in progress at IPTME.

\section{Acknowledgements}

The authors acknowledge the support from EPSRC (grant no. EP/D025354/1), and greatly appreciate the constructive contributions from members of both the VinylSUM Research Group (at IPTME) and the VinylSUM Network. Particular thanks go to the named companies that supplied polymers and additives.

This paper is based on a contribution to PVC2008, the tenth International PVC Conference, organised by the Polymer Society of the Institute of Materials, Mineral and Mining in Brighton, UK on 22-24 April 2008.

\section{References}

1. L. van der Ven, M. L. M. van Gemert, L. F. Batenburg, J. J. Keern, L. H. Gielgens, T. P. M. Koster and H. R. Fischer: Appl. Clay Sci., 2000, 17, 25-34.

2. Y. Lin, D. Li, D. G. Evans and X. Duan: Polym. Degrad. Stab., 2005, 88, 286-293.

3. Y. Lin, J. Wang, D. G. Evans and D. Li: J. Phys. Chem. Solids, 2006, 67, 998-1001.

4. R. Kalouskova, M. Novotna and Z. Vymazal: Polym. Degrad. Stab., 2004, 85, 903-909.

5. X. Wang: Polym. Mater. Sci. Eng., 2004, 91, 738-739.

6. X. Wang and Q. Zhang: Polym. Int., 2004, 53, 698-707.

7. Available at: http://www.kisuma.com.

8. Available at: http://www.sud-chemie.com

9. Alcamizer P93, 'Material Safety Data Sheet', 2004.

10. Sorbacid 911, 'Material Safety Data Sheet', 2004.

11. M. A. Algahtani: 'The effect of hydrotalcite mineral filler on properties and stability of rigid PVC', MSc Project Report, Loughborough University, Leicestershire, UK, 2007.

12. M. Gilbert and J. C. Vyvoda: Polymer, 1981, 22, 1134-1136.

13. M. Gilbert: Plast. Rubber Int., 1985, 10, 16-19.

14. L.-A. Fillot, C. Gauthier and P. Hajji: Proc. 9th IOM Int. PVC Conf., Brighton, UK, April 2005, IOM, 425-437.

15. W. V. Titow: 'PVC technology', 4th edn, Chap. 9; 1984, London, Elsevier Applied Science Publishers.

16. H. I. Gokcel, D. Balkose and U. Kokturk: Eur. Polym. J., 1999, 35, 1501-1508.

17. A. Al-Dossary: 'Use of UV and Raman spectroscopies to evaluate degradation in PVC', MSc Project Report, Loughborough University, Leicestershire, UK, 2007. 